\author{
한우보증씨수소 선발지수 개선에 관한 연구 \\ 김효선 $^{1} \cdot$ 황정미 ${ }^{1} \cdot$ 최태정 $^{1} \cdot$ 박병호 $^{1} \cdot$ 조광현 $^{1} \cdot$ 박철진 $^{2} \cdot$ 김시동 $^{*}{ }^{*}$ \\ ${ }^{1}$ 농촌진흥청 국립축산과학원, ${ }^{2}$ 농협중앙회 축산지원부
}

\title{
Research on the Reformation of the Selection Index for Hanwoo Proven Bull
}

\author{
Hyosun Kim ${ }^{1}$, Jeongmi Hwang ${ }^{1}$, Taejeong Choi ${ }^{1}$, Byongho Park ${ }^{1}$, Kwanghyun Cho ${ }^{1}$, Cheoljin Park ${ }^{2}$ and Sidong Kim ${ }^{1 *}$
}

${ }^{1}$ National Institute of Animal Science, RDA, ${ }^{2}$ National Agricultural Cooperatives Federation

\begin{abstract}
Hanwoo proven bulls have been selected since 1987 and consequently contributed to farmers for the improvement of beef cattle in Korea. The demand for the quality beef production as well as higher production efficiency was erupted after early 2000 as relatively cheap imported beef released. Therefore the pressure on the reformation of selection index for Hanwoo proven bulls have been piled up to furnish with Hanwoo's competitive. A total of 734 progeny test data were analyzed to select traits and their weights in the selection index to meet the beef market requirement. Regression analysis with stepwise selection method was used to select proper trait and its weight for selection index. A series of computer simulation was carried out to compare the currently using selection index with the alternate two selection indices proposed in this study. New selection index using standardized breeding values of Loin eye Muscle Area (LMA), Backfat Thickness (BFT) and Marbling Score (MS) with weight ratio 1:-1:6 was proposed. Results showed higher performance in improving MS and BFT gain by $22 \%$ and $31 \%$ still holding $86 \% \sim 89 \%$ of genetic gain achieved by current index in Carcass Weight (CW) and LMA when new selection index was fitted. Because, new index has little consideration for production cost, further research should be performed to build selection index including cost and income simultaneously.
\end{abstract}

(Key words : Hanwoo, Beef cattle, Proven bull, Selection index, Simulation)

$$
\text { 서 론 }
$$

1980년대 이전에는 국가단위 한우개량을 목적으로 축산진흥대회 와 같은 품평회를 통하여 우수축으로 입상한 수소를 정액생산용 씨 수소로 활용하였다. 그러나 표현형에 근거한 선발은 정확도가 낮아 개량량 향상에 어려움이 있어 정부에서는 능력검정을 통하여 능력 이 보증된 씨수소를 선발하기 위한 한우능력검정사업을 1983년에 시작하여, 1987년 처음으로 20 두의 한우보증씨수소를 선발하는 것 을 시작으로 현재에 이르고 있다(Paek, 2007; 농림수산식품부/농 촌진흥청, 2008). 한우보증씨수소는 매년 20 두 내외를 선발하고 있 다. 한우보증씨수소 선발초기에는 육량위주로 선발을 하였으나 1998년 이후에는 거세를 통한 후대검정성적분석을 실시하면서 육 량과 육질을 동시에 고려하여 선발을 실시하여 왔다. 그러나 그동 안의 한우 보증씨수소 선발지수는 성장형질인 도체중과 등심단면적 과 육질형질인 근내지방도를 각각 $1: 1: 2$ 로 포함하고 있어 (국립축산 과학원, 2008), 2000년 이후 쇠고기 수입자유화 등에 대한 한우육 품질고급화란 산업적 수요(허 등, 2000)를 적절히 만족시키지 못 한다는 우려가 있었다. 본 연구에서는 이러한 문제점을 점검해보고
육질개량을 강화하기 위한 한우보증씨수소 선발지수를 제안하고자 실시하였다.

\section{재료 및 방법}

\section{1. 표현형 자료 및 육종가 수집}

경락가격에 영향을 미치는 주요 도체형질을 조사하기 위하여 농 협 한우개량사업소에서 수행하고 있는 한우 후대검정자료를 수집하 였다. 수집한 자료는 후대검정 36차부터 40차까지의 자료 중 경락 가격이 있는 734두의 체중측정치 및 도체성적자료이며, 환경요인을 제거하고 경락가격에 미치는 영향을 보기 위하여 국가단위 한우유 전능력평가로부터 얻은 각 개체의 형질별 육종가를 함께 수집하였 다.

본 연구에 활용한 자료에 대한 기초통계를 Table 1에 나타내었 다. 도체형질에 대한 유전능력평가는 2007년 하반기 국가단위 한 우유전능력 평가결과의 개체별 육종가를 그대로 활용하였다. 국가 단위 한우유전능력평가에서 도체중, 등심단면적, 등지방두께는 각각

* Corresponding author: Sidong Kim, National Institute of Animal Scicnce, RDA. San 9, Uryongri Seonghwan-eup Cheonan-si, Choongnam-do, 330-801, Republic of Korea. Tel: +82-41-580-3359, Fax: +82-41-582-1248, E-mail: goldstar@ korea.kr 
Table 1. Basic statistics of data collected from Hanwoo progeny test program

\begin{tabular}{|c|c|c|c|c|c|c|c|c|c|c|c|c|c|c|}
\hline \multirow{2}{*}{\multicolumn{2}{|c|}{ Statistics }} & \multirow{2}{*}{$\mathrm{N}$} & \multirow{2}{*}{$\begin{array}{l}\text { Price } \\
\text { (Won) }\end{array}$} & \multirow{2}{*}{$\begin{array}{c}\text { Price/kg } \\
\text { (Won) }\end{array}$} & \multirow{2}{*}{$\begin{array}{c}\text { AS } \\
\text { (day) }\end{array}$} & \multicolumn{5}{|c|}{ Phenotypic Value } & \multicolumn{4}{|c|}{ Breeding Value } \\
\hline & & & & & & $\mathrm{CW}(\mathrm{kg})$ & $\mathrm{DP}(\%)$ & $\operatorname{LMA}\left(\mathrm{cm}^{2}\right)$ & $\mathrm{BFT}(\mathrm{mm})$ & MS & $\mathrm{CW}$ & LMA & BFT & MS \\
\hline \multicolumn{2}{|c|}{ MEAN } & 734 & $4,899,680.5$ & $13,737.7$ & 725.3 & 356.5 & 59.1 & 77.7 & 10.3 & 3.3 & 2.7 & 0.8 & 0.06 & 0.23 \\
\hline \multicolumn{2}{|l|}{ STD } & & $763,423.1$ & $1,531.3$ & 18.1 & 38.2 & 2.5 & 8.2 & 4.0 & 1.7 & 13.6 & 3.2 & 1.62 & 0.86 \\
\hline \multicolumn{2}{|l|}{ MIN } & & $2,148,653.0$ & 8000 & 674 & 231 & 12.4 & 42 & 3 & 1 & -94.9 & -14.7 & -3.22 & -1.80 \\
\hline \multicolumn{2}{|l|}{ MAX } & & $7,813,560.0$ & 2,0621 & 773 & 488 & 69.1 & 111 & 28 & 9 & 44.7 & 12.5 & 6.08 & 3.12 \\
\hline \multicolumn{2}{|c|}{ STD MIN } & - & - & - & - & -3.29 & -18.48 & -4.34 & -1.83 & -1.39 & -7.19 & -4.79 & -2.02 & -2.36 \\
\hline \multirow[t]{2}{*}{ STD 1} & MAX & - & - & - & - & 3.45 & 3.97 & 4.06 & 4.42 & 3.37 & 3.10 & 3.62 & 3.72 & 3.37 \\
\hline & & & \multicolumn{12}{|c|}{ Mean } \\
\hline \multirow[t]{5}{*}{ Batch } & 36 & 73 & $4,874,078.8$ & $13,067.8$ & 731.9 & 372.9 & 58.3 & 78.2 & 11.4 & 4.0 & 2.93 & 0.72 & 0.38 & 0.21 \\
\hline & 37 & 140 & $4,777,573.2$ & $14,393.4$ & 721.4 & 331.0 & 58.1 & 72.7 & 9.5 & 3.1 & 2.12 & 0.48 & -0.15 & 0.22 \\
\hline & 38 & 157 & $5,121,720.5$ & $14,200.1$ & 730.6 & 360.2 & 59.6 & 78.9 & 10.2 & 3.4 & 2.66 & 1.06 & -0.04 & 0.26 \\
\hline & 39 & 183 & $4,672,750.9$ & $13,323.5$ & 719.2 & 350.5 & 59.3 & 78.3 & 10.7 & 3.0 & 4.42 & 1.32 & 0.15 & 0.28 \\
\hline & 40 & 181 & $5,041,292.5$ & $13,518.1$ & 727.2 & 372.5 & 59.4 & 79.4 & 10.3 & 3.4 & 1.33 & 0.39 & 0.08 & 0.16 \\
\hline \multirow{3}{*}{$\begin{array}{l}\text { Birth } \\
\text { year }\end{array}$} & 2003 & 213 & $4,810,647.9$ & $13,939.1$ & 725.0 & 345.4 & 58.2 & 74.6 & 10.1 & 3.4 & 2.40 & 0.56 & 0.03 & 0.21 \\
\hline & 2004 & 322 & $4,896,719.8$ & $13,723.6$ & 726.6 & 356.2 & 59.5 & 78.7 & 10.5 & 3.2 & 3.66 & 1.21 & 0.08 & 0.25 \\
\hline & 2005 & 199 & $4,999,767.3$ & $13,544.8$ & 723.6 & 368.9 & 59.3 & 79.2 & 10.2 & 3.4 & 1.44 & 0.45 & 0.06 & 0.21 \\
\hline
\end{tabular}

Note: Every trait has same observation number. Abbreviations: $\mathrm{N}=$ Number of observation, $\mathrm{AS}=$ Age at slaughter, $\mathrm{CW}=\mathrm{Carcass}$ weight, DP $=$ Dressing Percent, LMA $=$ Loineye muscle area, BFT $=$ Backfat Thickness, MS $=$ Marbling score, STD MIN = minimum value after standardization, STD MAX = maximum value after standardization.

단형질 개체모형 (single trait Animal Model)을 적용하였고 근내 지방도는 7 등급으로 성적을 측정한 23 차 35 차까지의 자료와 9 등 급으로 측정한 36차 이후의 자료를 다형질 모형 (Multiple trait Animal Model)을 이용하여 분석하였다. 이때 근내지방도 (7등급, 9 등급) 형질간의 유전상관은 $95 \%$ 로 하였으며 오차공분산은 0 으로 하였다 (국립축산과학원, 2008). 분석모형은 아래와 같으며 각 형질 별로 동일한 모형을 적용하였다. 이때 적용한 각 형질별 유전력은 도체중, 등심단면적, 등지방두께, 그리고 근내지방도 (7등급, 9등급) 에서 각각 $0.36,0.38,0.36$ 및 0.5 였다.

$\mathrm{y}=$ batch_test_station + Bage_at_slaughter + animal + error

여기서, $\mathrm{y}$ 는 관측치, batch-test_station은 검정차수와 검정지의 교호작용으로 고정효과로 처리하였고, age_at_slaughter는 도축일 령으로 도체성적을 도축시 개체의 나이로 선형보정하기 위한 공변 량이며, animal은 개체효과로 임의효과, error는 임의오차이다(국 립축산과학원, 2008). 육종가 분석은 MTDFREML 패키지를 활용 하였다(Boldman 등, 1993).

2. 경락가격에 주요 영향을 주는 형질 선택 및 가중치 추정
경락가격에 영향을 주는 주요 형질을 선택하기 위하여 SAS의 REG 프로시저에서 STEPWISE 옵션을 주어 분석을 실시하였다 (SAS Inst. Inc., 2004). 분석시 각 형질별 분산과 단위가 다른 것 을 통일시키기 위하여 아래와 같이 각각의 평균과 표준편차를 활용 하여 표준화한 다음 분석에 활용하였다.

$$
S B V_{i j}=\frac{B V_{i j}-\overline{B V_{i}}}{S T D\left(B V_{i .}\right)}
$$

여기서, $\mathrm{SBV}_{\mathrm{ij}}$ : i번째형질의 $\mathrm{j}$ 번째 개체의 표준화 육종가, $\mathrm{BV}_{\mathrm{ij}}$ $: \mathrm{i}$ 번째형질의 $\mathrm{j}$ 번째 개체의 육종가, $\overline{B V_{i}}$ : $\mathrm{i}$ 번째형질의 육종가 평 균, $\operatorname{STD}\left(\mathrm{BV}_{\mathrm{i} .}\right)$ : i번째형질에 대한 육종가의 표준편차.

경락가격에 영향을 미치는 각 형질별 가중치를 계산하기 위하여 회귀분석을 실시하였다. 우선 각 형질의 표현형을 그대로 활용하여 변수선택을 할 때에는 검정차수, 출생년도, 표준화 도체중, 표준화 도체율, 표준화 등심단면적, 표준화 등지방두께 그리고 표준화 근 내지방도를 독립변수로 하고 $1 \mathrm{~kg}$ 당 단가를 종속변수로 하였다.

한편, 경락가격에 미치는 각 형질별 육종가에 대한 가중치를 계 산하기 위한 회귀분석에서는 $1 \mathrm{~kg}$ 당 단가를 종속변수로 하고 독립 변수로는 검정차수, 출생년도, 표준화 도체중 육종가, 표준화 등심 단면적 육종가, 표준화 등지방두께 육종가, 그리고 표준화 근내지 
방도 육종가(9등급)로 하였다. 각 형질별 표준화 이후 최소 및 최 대값은 Table 1에 나타낸 것과 같다. 이렇게 변수선택방법으로 얻 은 형질에 대한 회귀계수는 SAS GLM 프로시저를 이용하여 산출 하였으며, 이를 토대로 씨수소 선발지수의 가중치를 산출하였다 (SAS Inst. Inc., 2004).

\section{3. 모의시험을 통한 선발지수 비교}

선발지수를 변경할 때 개량효과가 어떻게 나타나는지를 비교하기 위하여 한우육종농가체계가 완전히 정착된 것을 가정하여 40 개의 한우육종농가와 1 개의 대규모농가(농협 한우개량사업소)를 암소축 군으로 하여 가임암소를 4,500 두 규모로 하고, 선발하는 씨수소는 40 두로 유지하되 농가 암소에 교배할 때에는 보증씨수소에서 상위 28 두와 후보씨수소 40 두를 통합하여 임의 교배를 실시하는 것으로 하고, 컴퓨터 모의시험을 실시하였다. 한우보증씨수소 선발을 위한 능력검정을 시작한 것이 1983년인 것을 흉내 내기 위하여 모의시 험은 1983년부터 2015년까지 한우육종농가체계를 운영하는 것으 로 하고, 보증씨수소 선발지수는 1987년부터 적용하였다. 이때 보 증씨수소의 선발은 추정육종가를 기준으로 기존에 사용하던 것과 $\left(\mathrm{I}_{1}\right)$, 앞의 분석결과를 토대로 가중치를 설정한 것 $\left(\mathrm{I}_{2}\right)$, 그리고 상 대비교를 위해 임의로 가중치를 설정한 선발지수 $\left(\mathrm{I}_{3}\right)$ 를 이용하여 실 시하였다. 그러나 후보씨수소 선발은 모두 현재와 같이 12 개월령체 중과 근내지방도의 육종가를 표준화한 다음 각각 $2: 1$ 의 가중치를 주어 선발하였다.

$$
\begin{aligned}
& \mathrm{I}_{1}=1 \times \text { SBV_CW }+1 \times \text { SBV_LMA }+2 \times \text { SBV_MS } \\
& \mathrm{I}_{2}=1 \times \text { SBV_LMA }-1 \times \text { SBV_BFT }+6 \times \text { SBV_MS } \\
& \mathrm{I}_{3}=4 \times \text { SBV_MS }-1 \times \text { SBV_BFT }
\end{aligned}
$$

여기서, $\mathrm{SBV} \mathrm{CW}=$ 도체중의 표준화 육종가, $\mathrm{SBV} \mathrm{BFT}=$ 등지 방두께의 표준화 육종가, $\mathrm{SBV} \mathrm{MS}=$ 근내지방도의 표준화 육종가 이다.
한편 모의시험에서 개체의 표현형은 아래와 같은 선형모형을 적 용하여 생성하였다.

$$
y_{i j k d}=\text { year }_{i}+\operatorname{sex}_{j}+\text { herd } d_{k}+\text { animal }_{i j k l}+\text { error }_{i j k l}
$$

여기서, $y_{i j k l}=\mathrm{i}$ 번째 년의 $\mathrm{j}$-번째 성, $\mathrm{k}$ 번째 축군에 속하는 1 번째 개체의 관측치, $y^{2 e a r_{i}}=\mathrm{i}$ 번째 년도효과 (1978 2015), $\operatorname{sex}_{j}=\mathrm{j}$ 번째 성의 효과(male \& female), $h e r d_{k}=\mathrm{k}$ 번째 축군 효과(육종농가: $1 \sim 40$, 농협한우개량사업소: 41), $a_{n i m a l} i j l=1$ 번째 개체의 상가적 유전효과, $\mathrm{error}_{i j k l}=$ 임의오차이다.

모의시험에 적용한 모수는 후대검정 23 차 40 차까지의 자료와 당 대검정 25 차 52 차의 자료를 통합하여 각 형질은 국가단위 한우유 전능력평가시 적용하는 통계모형 (국립축산과학원, 2008)으로 DFREML 패키지 (Meyer, 1988)를 이용하여 추정하였으며 Table 2에 나타낸 것과 같다. 모의시험에서 적용한 개량체계는 Fig. 1 에 나타낸 것과 같다. 이외에 축군의 나이분포 등 기타 모의시험과 관련한 사항은 $\operatorname{Kim}(2007)$ 의 모의시험연구와 동일하게 적용하였고, 모의시험 프 로그램 역시 $\mathrm{Kim}$ (2007)의 연구에서 활용한 것을 그대로 사용하였 다. 모의시험은 윈도우 운영체제가 설치된 $\mathrm{PC}$ 를 활용하였다.

\section{결과 및 고찰}

\section{1. 일반성적}

한우 후대검정사업을 통하여 얻은 경락가격이 있는 자료를 토대 로 본 연구에 활용한 개체의 성적을 살펴보면 24개월령 출하에 평 균도체중은 $356.5 \mathrm{~kg}$, 경락 가격은 약 490 만원 $(\mathrm{kg}$ 당 단가 13,738 원), 등심단면적은 $77.7 \mathrm{~cm}^{2}$, 등지방두께는 $10.3 \mathrm{~mm}$, 근내지방도는 3.3점인 것으로 나타났다 (Table 1). 이 성적을 2007년 거세우 전 국평균성적과 비교하면, 도체중, 등심단면적, 등지방두께 및 근내지

\begin{tabular}{|c|c|c|c|c|c|c|c|c|c|c|c|}
\hline \multirow[b]{2}{*}{ Traits } & \multicolumn{5}{|c|}{ Genetic and Error variance-covariance ${ }^{1}$} & \multirow{2}{*}{ Traits $^{3}$} & \multicolumn{5}{|c|}{ Heritability, genetic and error correlation $^{2}$} \\
\hline & $\begin{array}{c}\text { WT12 } \\
(\mathrm{kg})\end{array}$ & $\begin{array}{l}\mathrm{CW} \\
(\mathrm{kg}) \\
\end{array}$ & $\begin{array}{l}\text { LMA } \\
\left(\mathrm{cm}^{2}\right)\end{array}$ & $\begin{array}{c}\text { BFT } \\
(\mathrm{mm}) \\
\end{array}$ & MS & & WT12 & $\mathrm{CW}$ & LMA & BFT & MS \\
\hline & 344.7 & 264.6 & 46.1 & 0.6 & -0.7 WT12 & & & 0.75 & 0.52 & 0.01 & -0.04 WT12 \\
\hline & & 356.7 & 55.2 & 7.9 & $1.6 \mathrm{CW}$ & & 0.32 & & 0.61 & 0.19 & $0.08 \mathrm{CW}$ \\
\hline WT12 & 728.1 & & 22.7 & -2.3 & 0.8 LMA & & & 0.33 & & -0.22 & 0.17 LMA \\
\hline $\mathrm{CW}$ & 499.1 & 715.4 & & 4.7 & $0.1 \mathrm{BFT}$ & CW & 0.69 & & 0.38 & & $0.05 \mathrm{BFT}$ \\
\hline LMA & 42.1 & 81.4 & 37.4 & & 1.0 MS & LMA & 0.26 & 0.50 & & 0.44 & \\
\hline BFT & 23.7 & 29.1 & 3.2 & 6.1 & & BFT & 0.36 & 0.44 & 0.21 & & 0.43 \\
\hline MS & 0.9 & 3.1 & 1.0 & 0.2 & 1.3 & MS & 0.03 & 0.10 & 0.14 & 0.07 & \\
\hline
\end{tabular}
방도의 전국평균은 각각 $397.7 \mathrm{~kg}, 82.9 \mathrm{~cm}^{2}, 12.3 \mathrm{~mm}$, 그리고 4.9점으로 나타나 등지방두께를 제외하고는 후대검정우의 성적이

Table 2. Parameters used in the computer simulation to compare performance of selection indices

Note: ${ }^{1}$ Variances are on the diagonal and covariances are on the off diagonal. The variance-covariances were estimated by DFREML using data from progeny test batch of $23 \sim 40$ and performance test batch of $25 \sim 52 .{ }^{2}$ Heritabilities are on the diagonal, genetic correlations are above diagonal and error correlations are below diagonal. ${ }^{3}$ Abbreviations: WT12 = Body weight at Age $12 \mathrm{mo}$., $\mathrm{CW}=$ Carcass weight, LMA $=$ Loineye muscle area, BFT $=$ Backfat Thickness, $\mathrm{MS}=$ Marbling score 


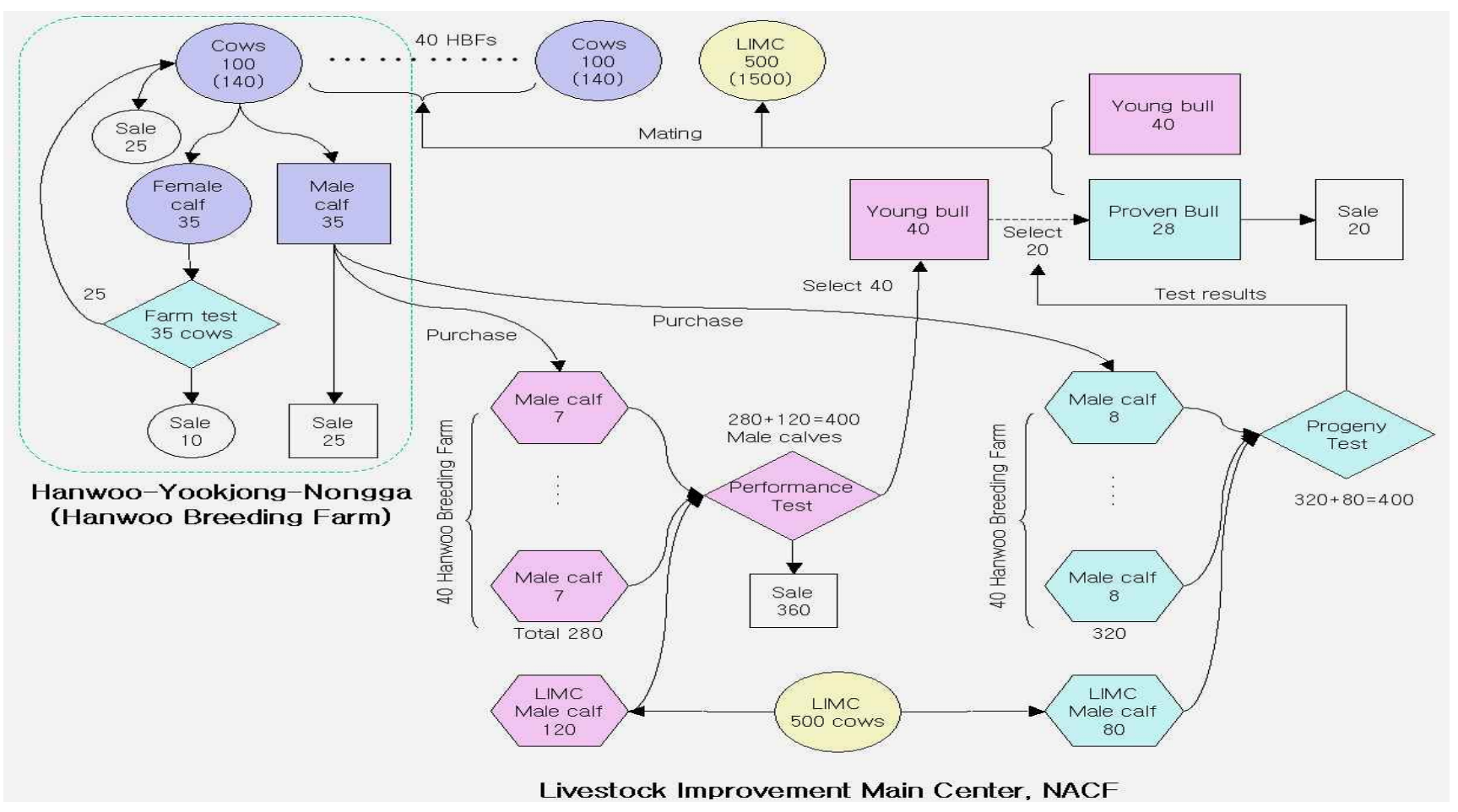

Fig. 1. Simulated Breeding Scheme adapted from Kim (2007); Hanwoo-Yookjong-Nongga (Hanwoo Breeding Farm)

낮게 나타났다 (축산물등급판정소, 2008). 그러나 이러한 차이는 일 반적으로 거세우 평균출하시기가 30개월령정도임을 감안하면 후대 검정성적이 전국평균성적에 비해 떨어진다고 보기는 어려울 것으로 판단된다. 분석을 위하여 표준화한 경우 표현형에서 도체율에서 -18.48 로 극단값을 나타낸 것과 유전능력에서 도체중과 등심단면 적에서 각각 -7.19 및 -4.79 의 극단값이 나타난 것을 제외하고 는 적절한 분포를 보이고 있는 것으로 나타났다. 분석에서 도체율 극단치는 제거하였으나 체중과 등심단면적의 자료는 그대로 이용하 였다. 분석에 이용한 자료를 검정차수별로 살펴보면 근내지방도가 36 차에서 4.0 으로 다른 차수보다 조금 높게 나타났으며 이는 검정 체계가 국립축산과학원에서 농협으로 이관된 첫해에 발생한 사양관 리상의 변화에 따른 것으로 사료된다.

\section{2. 경락가격에 영향을 주는 주요 형질 분석}

경락가격에 영향을 미치는 주요 형질을 분석하기 위하여 회귀분 석의 변수선택법을 이용한 결과는 다음과 같다.

\section{(1) 표현형을 이용한 형질별 가중치 추정}

각 형질의 표현형값을 표준화한 다음 이를 독립변수로 하고 $1 \mathrm{~kg}$ 당 경락가격을 종속변수로 하여 변수선택을 실시한 결과를 Table 3에 나타내었다.

선택된 형질은 근내지방도와 등지방두께, 등심단면적과 도체율이 었으며, 도축시 시장가격과 동기군의 차이를 설명하는 변수인 출생
년도와 검정차수 역시 주요 변수인 것으로 나타났다. 그러나 부분 결정계수로 살펴볼 때 근내지방도가 0.5129 로 경락가격을 결정짓 는 가장 큰 변수인 것으로 나타났으며 이는 근내지방도가 육질등급 을 판정하는 가장 큰 요인인 것과 일치하는 것으로 사료되며, 등지 방두께의 기여도가 그 다음인 것으로 나타나 현재 육량지수 $(\mathrm{I}=$ $68.184-[0.625 \times$ 등지방두께 $(\mathrm{mm})]+\left[0.130 \times\right.$ 등심단면적 $\left.\left(\mathrm{cm}^{2}\right)\right]$ - $[0.024 \times$ 도체중량 $(\mathrm{kg})]+3.23$, 농림부, 2007)에서 알 수 있는 것과 같이 등지방두께가 육량을 결정짓는 요인인 점으로 볼 때 변 수 선택은 육질과 육량을 적절히 설명하는 변수로 선택된 것을 알 수 있다. 한편 이들 형질간의 상대적 중요도를 알아보기 위하여 도 체율의 회귀계수에 대하여 타 형질의 회귀계수를 비교하면 근내지 방도는 13.0배, 등지방두께는 -2.6 배 (얇은 것이 좋으므로 회귀계 수는 음의 수로 나타남), 그리고 등심단면적은 1.4 배인 것으로 나 타났다. 따라서 표현형을 기준으로 하여 선발을 실시한다면 각 형 질의 표준화 값에 이러한 비율을 적용하여 선발하면 높은 경락가격 을 받을 수 있는 개체를 선발할 수 있을 것으로 추측된다. 즉 근내 지방도, 등지방두께, 등심단면적, 도체율에 대하여 각각 $13,-2.6$, 1.4 , 그리고 1.0 의 가중치를 준 선발지수를 활용할 수 있을 것으로 보인다. 그러나 표현형은 개체가 처한 환경에 따라 변화하는 정도 가 크기 때문에 유전능력을 평가할 수 없는 경우에만 활용하는 것 이 바람직할 것이다.

선발지수는 가축의 경제적 가치를 효과적으로 개량하기 위해 사 용하는 것으로 이를 산출하기 위해서는 각 형질의 표현형(공)분산, 유전(공)분산, 각 형질에 대한 상대적 경제가치에 대한 통계량이 
Kim et al. ; Reformation of the Selection Index for Hanwoo Proven Bull

Table 3. Summary of Stepwise Selection of traits when the price per kilogram was regressed on the standardized value of each trait

\begin{tabular}{clcccrrr}
\hline Step & Variable Entered $^{1}$ & Partial R-Square & Model R-Square & $\mathrm{C}(\mathrm{p})$ & $\mathrm{F}$ Value & Pr $>\mathrm{F}$ & Estimate $^{2}$ \\
\hline \hline 1 & MS $^{3}$ & 0.5129 & 0.5129 & 72.4731 & 770.80 & $<.0001$ & $1108.98(13.0)$ \\
2 & BFT & 0.0178 & 0.5307 & 45.1067 & 27.77 & $<.0001$ & $-221.44(-2.6)$ \\
3 & Birth year & 0.0097 & 0.5404 & 31.1586 & 15.38 & $<.0001$ & - \\
4 & Batch number & 0.0082 & 0.5486 & 19.7160 & 13.18 & 0.0003 & - \\
5 & LMA & 0.0079 & 0.5565 & 8.6842 & 12.98 & 0.0003 & $122.68(1.4)$ \\
6 & DP & 0.0028 & 0.5593 & 6.0005 & 4.69 & 0.0307 & $85.60(1.0)$ \\
\hline
\end{tabular}

Note: ${ }^{1}$ All variables except birth year and batch number are standardized. ${ }^{2}$ Regression coefficients are estimated with SAS GLM procedure with Birth year and Batch number as class variable, and relative proportions to DP are in parenthesis. The model's $\mathrm{R}^{2}$ was 0.559 .

${ }^{3}$ Abbreviations: WT12 = Body weight at Age 12mo., CW $=$ Carcass weight, DP $=$ Dressing Percent, LMA $=$ Loineye muscle area, $\mathrm{BFT}=$ Backfat Thickness, MS $=$ Marbling score.

필요하다(이 등, 1985). 그러나, 한우의 경우 상대적 경제가치를 산출하기 위해 필요한 사료비 등 제반 경비에 대한 산출이 실질적 으로 어렵기 때문에 경제가치 계산에 비용부분을 감안하기가 곤란 한 문제가 있어 본 연구에서는 경락가격(조수익)에 영향을 미치는 요인만으로 한정시켜 형질별 가중치를 분석하였기 때문에 해석에 주의가 필요하다.

\section{(2) 육종가를 이용한 형질별 가중치 추정}

개체별로 추정한 육종가를 활용할 경우 일반적인 선발지수를 구 할 때 표현형(공) 분산을 계산할 필요 없이 유전(공) 분산을 활용 하면 되기 때문에 지수 계산이 단순해진다. 또한 국가단위 유전능 력평가를 통하여 개체별 육종가를 추정할 수 있기 때문에 표현형을 이용하는 기존의 선발지수보다는 더 정확한 선발이 가능하다 하겠 다. 본 연구에서는 각 개체의 형질별 육종가를 표준화하여 $1 \mathrm{~kg}$ 당 경락가격에 미치는 주요 형질을 선택하고 그 형질에 대한 가중치를 추정하여 Table 4에 표시하였다. 육종가를 이용하여 분석하였을 때
경락가격에 가장 큰 영향을 미치는 형질은 표현형과 마찬가지로 근 내지방도로 나타났으며 (부분 결정계수 0.5006), 등심단면적과 등지 방두께, 그리고 도체중이 포함되는 것으로 나타났다. 또한 검정차 수보다는 생년이 선택되었는데 이는 시기에 따른 경락가격의 변동 폭을 설명하는 변수인 것으로 판단된다. 각 형질의 상대적 가중정 도를 알아보기 위하여 각 형질별로 추정된 회귀계수를 등심단면적 에 대비하여 계산하면 근내지방도가 10.2 배, 등지방두께가 -2 배 (얇은 것이 좋으므로 회귀계수는 음의 값으로 나타남), 도체중이 1.3 배인 것으로 나타나 표현형으로 추정한 가중치와 유사한 경향을 나타내었다. 한편 도체중과 등심단면적간에는 높은 정의 상관관계 가 있고 현행 등급판정기준에서 정하는 육량지수식에서 도체중이 작은 값이지만 음의 가중치를 가지고 있는 것을 감안하여 도체중을 선발지수에서 누락시키고 회귀계수를 다시 추정한 후, 등지방두께 에 대한 회귀계수 $(-1.0$ 배)를 기준으로 비교하였을 때, 근내지방도 는 6.4 배, 등심단면적은 1.1 배로 나타났고 결정계수는 0.540 으로, 형질을 모두 포함시켰을 때의 0.543 과 큰 차이가 나타나지 않는

Table 4. Summary of Stepwise Selection of traits when the price per kilogram was regressed on the standardized breeding value (BV) of each trait

\begin{tabular}{clccccccc}
\hline Step & Variable Entered $^{1}$ & Partial R-Square & Model R-Square & C $(\mathrm{p})$ & F Value & Pr $>$ F & Estimate $^{2}$ & Estimate $^{3}$ \\
\hline \hline 1 & MS $^{4}(\mathrm{BV})$ & 0.5006 & 0.5006 & 64.9822 & 733.73 & $<.0001$ & $1081.12(10.2)$ & $1067.19(6.4)$ \\
2 & LMA (BV) & 0.0165 & 0.5171 & 40.7500 & 24.94 & $<.0001$ & $106.24(1.0)$ & $187.04(1.1)$ \\
3 & BFT (BV) & 0.0119 & 0.5290 & 23.7502 & 18.50 & $<.0001$ & $-207.80(-2.0)$ & $-166.40(-1.0)$ \\
4 & Birth year & 0.0087 & 0.5377 & 11.8785 & 13.74 & 0.0002 & - & - \\
5 & CW (BV) & 0.0054 & 0.5431 & 5.3346 & 8.55 & 0.0036 & $142.00(1.3)$ & - \\
$\mathrm{R}^{2}$ & - & - & - & - & - & - & 0.543 & 0.540 \\
\hline
\end{tabular}

Note: ${ }^{1}$ All variables except birth year are standardized breeding value. ${ }^{2}$ Regression coefficients are estimated with SAS GLM procedure with Birth year as class variable, and relative proportions to LMA are in parenthesis. ${ }^{3}$ Regression coefficients estimated without CW because LMA is highly correlated with CW, and relative proportions to BFT are in parenthesis. ${ }^{4}$ Abbreviations: WT12 = Body weight at Age $12 \mathrm{mo} ., \mathrm{CW}=$ Carcass weight, $\mathrm{LMA}=$ Loineye muscle area, BFT $=$ Backfat Thickness, $\mathrm{MS}=$ Marbling score. 
것으로 나타나, 도체중을 고려하지 않을지라도 큰 문제가 없을 것 으로 사료되었다. 이 경우 선발지수는 상대적 비율을 단순화하여 근내지방도, 등심단면적과 등지방두께를 각각 6,1 , 및 -1 로 사용 하는 것이 가능할 것으로 보인다. 한편 선발지수에서 누락된 도체 중은 지수에 포함된 경우보다는 그 개량정도가 낮겠지만 등심단면 적과의 유전상관에 따른 상관반응으로 등심단면적이 개량됨에 따라 함께 개량될 것으로 추측된다(이 등, 1985). 한편, 육종가를 기반 으로 경락가격에 영향을 미치는 주요 형질을 선택하고 각 형질별 가중치를 구하여 적절한 선발지수를 산출하였다고 하더라도, 앞의 표현형으로 산출한 선발지수식과 같이 생산에 소요되는 경비 산출 이 되지 않았기 때문에 본 지수 역시 해석에 주의가 필요하다.

\section{3. 모의시험을 통한 선발지수 비교}

표준화한 도체중, 등심단면적, 근내지방도의 육종가에 대하여 $1: 1: 2$ 의 가중치를 적용하는 기존의 선발지수 $\left(\mathrm{I}_{1}\right)$ 와, 본 연구에서 제 안한 표준화 등심단면적, 등지방두께 그리고 근내지방도 육종가에 대해 1:-1:6의 가중치를 부여한 선발지수 $\left(\mathrm{I}_{2}\right)$, 그리고 근내지방도와 육량에 큰 영향을 미치는 등지방두께를 각각 4:-1의 가중치를 준 선발지수 $\left(\mathrm{I}_{3}\right)$ 를 컴퓨터 모의시험을 통하여 비교하였다. 각 선발지수 의 적용시기는 처음으로 보증씨수소가 선발되는 시기인 1987년이 다(농림수산식품부/농촌진흥청, 2008). 이는 기존의 한우개량체계 를 그대로 묘사하기 위하여 한우보증씨수소 선발을 위한 능력검정 사업과 시기를 일치시킨 것으로, 개체별 추정육종가를 기준으로 선 발을 실시하기 위하여 1987년부터 유전능력평가를 실시하였고 후 보씨수소의 선발은 기존의 후보씨수소 선발지수식(표준화 12개월

Table 5. Genetic changes of population by selection index

\begin{tabular}{|c|c|c|c|c|}
\hline \multirow{2}{*}{\multicolumn{2}{|c|}{ Trait and genetic gain }} & \multicolumn{3}{|c|}{ Mean of true breeding value (relative ratio to $\mathrm{I}_{1}$ ) } \\
\hline & & \multirow{2}{*}{$\frac{I_{1}}{245.81}$} & \multirow{2}{*}{$\frac{\mathrm{I}_{2}\left(\mathrm{I}_{2} / \mathrm{I}_{1} \%\right)}{40.76(89 \%)}$} & $\mathrm{I}_{3}\left(\mathrm{I}_{3} / \mathrm{I}_{1} \%\right)$ \\
\hline \multirow{2}{*}{$\mathrm{CW}^{1}$} & Population Mean at 2015 & & & $34.83(76 \%)$ \\
\hline & $\Delta \mathrm{G} /$ year & 1.64 & $1.46(89 \%)$ & $1.24(76 \%)$ \\
\hline \multirow{2}{*}{ LMA } & Population Mean at 2015 & 9.90 & $8.54(86 \%)$ & $8.51(86 \%)$ \\
\hline & $\Delta \mathrm{G} /$ year & 0.35 & $0.31(89 \%)$ & $0.30(86 \%)$ \\
\hline \multirow{2}{*}{ BFT } & Population Mean at 2015 & 0.55 & $0.38(69 \%)$ & $-1.02(-185 \%)$ \\
\hline & $\Delta \mathrm{G} /$ year & 0.02 & $0.02(100 \%)$ & $-0.04(-200 \%)$ \\
\hline \multirow{2}{*}{ MS } & Population Mean at 2015 & 2.60 & $3.17(122 \%)$ & $2.81(108 \%)$ \\
\hline & $\Delta \mathrm{G} /$ year & 0.09 & $0.11(122 \%)$ & $0.10(111 \%)$ \\
\hline
\end{tabular}

Note: $\mathrm{I}_{1}=\mathrm{CW}+\mathrm{EMA}+2 \mathrm{MS}, \mathrm{I}_{2}=\mathrm{EMA}-\mathrm{BF}+6 \mathrm{MS}, \mathrm{I}_{3}=4 \mathrm{MS}-\mathrm{BF},{ }^{1}$ Abbreviations: $\mathrm{WT} 12=$ Body weight at Age $12 \mathrm{mo} ., \mathrm{CW}=\mathrm{Carcass}$ weight, LMA $=$ Loineye muscle area, $\mathrm{BFT}=$ Backfat Thickness, $\mathrm{MS}=$ Marbling score.

\section{$\mathrm{I}_{1} . \mathrm{CW}+\mathrm{EMA}+2 \mathrm{MS}$}

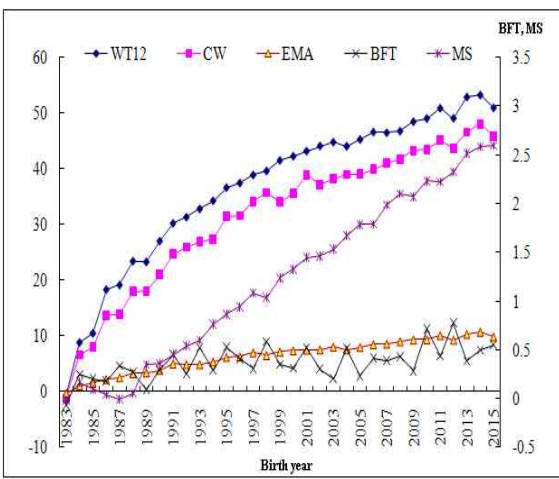

I2. EMA-BF+6MS

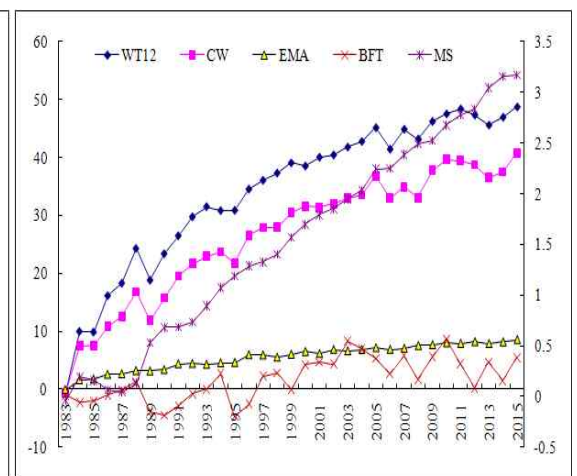

I. $4 \mathrm{MS}-\mathrm{BF}$

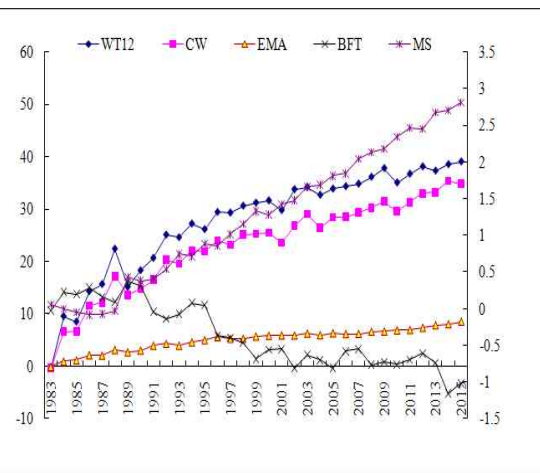

Fig. 2. Comparison of genetic trends between selection indices.

Means of animals' true breeding values by their birth year were plotted. The $I_{2}$ index showed better performance in MS than $I_{1}$ and $I_{2}$, whereas I1 showed higher outputs in CW and LMA by $11 \sim 14 \%$. $I_{3}$ index showed similar result on MS and BFT and it might produce "1++A" grade, however CW and LMA gain had diminished compare to other indices and total income would be cut by amount of body weight reduction. 
령체중 육종가: 표준화 근내지방도 육종가 $=2: 1$ )을 그대로 적용 하였다.

모의시험을 통하여 각 선발지수가 각 형질별로 얼마만큼의 개량 량을 획득하였는지를 알아보기 위하여 2015년에 태어난 개체의 참 육종가를 기준으로 하여 각 형질별 평균육종가와 년당 개량량을 Table 5에, 각 형질별 참육종가 평균의 변화정도를 Fig. 2에 나타 내었다. 2015년을 기준으로 볼 때, 기존 선발지수 $\left(\mathrm{I}_{1}\right)$ 는 도체중이 45.81 , 등심단면적이 9.90 , 등지방두께는 0.55 , 근내지방도는 2.60 으로 나타난 반면, 등지방두께를 새로 포함시키고 근내지방도에 대 한 가중치를 강화한 선발지수 $\left(\mathrm{I}_{2}\right)$ 에서는 위 형질의 평균육종가가 각각 $40.76,8.54,0.38$, 그리고 3.17 로 나타나 도체중이 선발지수 에서 제외되었음에도 불구하고 도체중이 기존 지수로 선발한 것의 $89 \%$ 에 이르는 개량효과를 보이는 것으로 나타났다. 한편, 근내지 방도는 기존지수에 비해 $122 \%$ 우수한 것으로 나타났으며 등지방 두께는 기존지수의 $69 \%$ 로써 기존지수보다 개선된 것으로 나타나 기존지수가 등지방두께를 포함하지 않아 육량등급이 저하되는 문제 를 어느 정도 해결할 수 있는 것으로 사료된다. 한편 근내지방도와 등지방두께만을 고려한 선발지수 $\left(\mathrm{I}_{3}\right)$ 에서 등지방두께는 기존지수보 다 $185 \%$ 이상 개선되어 육량을 떨어뜨리는 등지방두께에 대한 개 량은 확실하지만 상대적으로 도체중과 등심단면적 개량이 후보씨수 소 선발지수에만 의존함으로써 기존지수의 $76 \%$ 86\% 정도의 효율 을 가지고 있는 것으로 나타났고 근내지방도는 기존지수보다 약 $8 \%$ 정도 개선이 되는 것으로 나타나 육질 및 육량등급 개선효과 가 있을 것으로 예상되지만, 도체중이 작아 최종수익이 줄어들어 그 효과가 반감될 것으로 보인다.

본 결과로 미루어 볼 때 선발지수 $\left(\mathrm{I}_{2}\right)$ 를 한우 보증씨수소 선발에 활용하게 되면 근내지방도 개선효과가 커 육질고급화 요구를 충족 시킴과 동시에 육량등급이 저하되는 문제를 해결할 수 있을 것으로 사료된다. 그러나 체중증가는 지속되지만 기존지수보다는 약 $10 \%$ 정도 감소할 것으로 예상된다. 한편, 본 모의시험은 여러 가지 제 약조건을 가정하여 그 결과를 도출한 것으로 실제 상황에서는 모의 시험과 다르게 나타날 수 있으므로, 실제 적용에는 상당한 주의가 필요할 것이다.

\section{요 약}

본 연구를 통하여 도체성적에 대한 경제적 가치를 산출하고 이를 토대로 새로운 한우 보증씨수소 선발지수를 제안하였다. 선발지수 는 경제적으로 중요한 형질에 필요한 만큼의 가중치를 주어 개체를 효과적으로 선발하는 데 도움을 주는 강력한 도구로써 농장에서 일 어나는 수입과 지출을 고려하여 선발지수를 산출할 수 있다. 최근 에는 이러한 선발지수를 농장에서 자기 농장에 알맞게 개발할 수 있도록 인터넷을 통하여 서비스를 제공하고 있다 (Lazenby 등. 1998). 그러나 우리나라는 조수입의 산출은 가능하지만 경비를 정 확히 산출할 수 있는 농가가 드물기 때문에 아직 농가차원에서 적 절한 선발지수를 만들어 사용하는 것은 어려운 것으로 보인다. 또
한 이러한 이유로 인하여 한우 보증씨수소를 선발함에 있어 비용부 분을 고려하지 못하고 조수익에 의존하여 지수를 만들 수밖에 없는 문제를 안고 있다. 아울러 선발에서 고려할 수 있는 갈비생산량, 등심생산량, 안심생산량, 정육율 등 도체에서 얻을 수 있는 다양한 형질의 개발과 측정이 필요하고, 암소선발을 위해서는 농가의 번식 기록을 통해 얻을 수 있는 번식형질에 대한 조사가 이루어져야 미 국과 같이 다양한 선발지수를 개발하고 활용 (Greiner, 2006)하여 다양화로 나가는 소비시장에 적절히 대응해 나갈 수 있을 것이다.

$$
\text { 사 사 }
$$

본 연구는 농촌진흥청 박사후 연수생 지원사업에 의하여 수행되 었습니다.

\section{인 용 문 헌}

Boldman, K. G., Kriese, L. A. and Van Vleck, L. D. 1993. A Manual for the Use of MTDFREML: A Set of Programs of Variances and Co Variances. Dep. Agric. Res. Serv., Lincoln, NE.

Greiner, Scott P. 2006. Utilizing Multi-trait index EPDs. Livestock update, December 2006. Online. Available :http://sites.ext.vt.edu/ newsletter-archive/livestock/aps-06_12/ aps-385.html.

Ignacy Misztal. 2008. BLUPF90 - a flexible mixed model program in Fortran 90. Online. Available :http://nce.ads.uga.edu/ ignacy/ numpub/blupf90/docs/blupf90.pdf.

Kim, Sidong. 2007. Simulation studies on comparative genetic gains from different bull selection strategies of Korean cattle (Hanwoo, Bos taurus Coreanae). Ph. D. Dissertation. Seoul National University.

Lazenby, M. T., Miller, S. P., Banks, L. R. and Wilton, J. W. 1998. Customized sire selection on the internet. 98/99 Ontario beef research update. Online. Available : http://bru.aps.uoguelph.ca/ Articles98-99/1998-pg4.pdf.

Meyer, K. 1988. DFREML - a set of programs to estimate variance components under an. Individual Animal Model. J. Dairy Sci. 71 : Supplement 2, 33-34.

Paek, Bong Hyun. 2007. Overview of beef cattle (Hanwoo) production in Korea. Proceedings of 2nd Korea-U.S.-Japan International Joint Symposium. Texas A\&M and NIAS, RDA.

SAS Inst. Inc. 2004. SAS/STAT 9.1 user's Guide. SAS Inst. Inc., Cary, NC, USA.

국립축산과학원. 2008. 한우유전능력평가보고서 (2007년도 하반기). 국립축 산과학원 (발간등록번호:11-1390217-00045-09).

농림수산식품부/농촌진흥청. 2008. 가축개량관련자료 2007. pp27-34. 국립 축산과학원 (발간등록번호 11-1390271-000034-10). 
이기만, 박영일, 오봉국. 1985. 신고 가축육종학. 향문사.

최태정, 김시동, Agapita J. Salces, 백동훈. 2006. 한우의 성장 및 도체형 질에 대한 유전모수 추정. 한국동물자원과학회지 48(6):759-766.

축산물등급판정소. 2008. 2007 축산물등급판정 통계연보. 축산물등급판정 소, 경기도 군포시.
허 덕, 정민국, 유철호, 신승열, 최정섭. 2000. 쇠고기 수입자유화와 한우 산업 발전방안. 한국농촌경제연구원 (연구보고 R413/2000.12). 농림부. 2007. 축산물등급판정세부기준. 농림부고시 제2007-40호. (접수일자 : 2009. 11. 2 / 수정일자: 2010. 4. 14 / 채택일자 : 2010. 4. 14) 